\title{
The design of monetary institutions: an accounting and economics perspective
}

\author{
Romar Correa \\ Department of Economics, University of Mumbai, Mumbai 400 098, INDIA \\ Email: romarcorrea10@gmail.com
}

\begin{abstract}
We enter meeting ground between two agendas of the heterodox economics programme; the stock-flow-consistent models pioneered by Wynne Godley, and the monetary circuit approach researched in France and Italy. The objective is to present a National Income accounting approach to two innovations in payments mechanisms: deposit-creating institutions and conditional cash transfers.
\end{abstract}

Keywords: deposit-creating institutions; unconditional cash transfers.

\section{Introduction}

The common core of the approaches to monetary macroeconomics to be synthesized below can be culled from Georg Simmel's magnum opus [1]. The methodological motive is pure objectivity, the divorce of the object from any relationship with the subject [1: 78]. The relationship is formed through production. Direct consumption is not an economic act [1: 80]. Production is carried out for the purpose of exchange with another object who is a mirror. The two objects, thereby, enter into a reciprocal objective relationship. Value and price are one and the intellectual industry involved in working out the transformation of one into the other is superfluous [1: 94]. The evolution of money is marked by the impulse towards centralization of the institutions that guarantee its value [1: 153]. The importance of metal markedly recedes and the functional value of money, underpinned by social institutions, comes to the fore [1: 184]. Metal, after all, was originally always private property. A landmark in this connection is the issue of government bonds before the eighteenth century that first created a claim on state revenues. The certainty of payment depended on complete confidence of the state's ability to pay.

Money is linked to the marginal [1: 221]. It is impossible to exclude anyone from the monetary process. A monetary economy oriented towards the unemployment of the poor would emphasize the consumption and production of basics [1: 233]. Such an economy would, naturally, possess a huge agrarian sector.

A contemporary connection exists with two full-fledged hubs of non neoclassical research activity that stand out for their accounting purity and constructive appeal. Stock-flow-consistent modeling was invented, in a sense, by Wynne Godley and is developed, among other places, at the Jerome Levy Institute, New York. The practitioners introduce the discipline of double-entry bookkeeping to National Income identities. Rows and columns in Godley matrices must sum correctly, a positive item here must be backed by an item of identical magnitude but opposite sign there. Of the same methodological fraternity, a monetary circuit approach to macroeconomics is energetically being studied in France [see 2 for a survey] and Italy [3 is a good survey]. The basic principle is similar to the Anglo-Saxon; a circuit must be opened and closed, a number in the first instance must be backed by the same figure in the second. Money, as elaborated by Bernard Schmitt, is the fulcrum of three points in triad. The three poles are the bank, the firm, and the worker. Money is destroyed the instant it is created or, as Alain Parguez would explain, when firms discharge their debts to banks. One inspiration is the input-output economics of Quesnay. Of interest to us is his two-sector, three-class typology [4]. The sectors are agriculture and manufacturing and the classes are producers of agricultural commodities, of manufactures, and landlords. Say is another influence in his emphasis on demand [5]. He highlighted the purchasing power embodied in money to keep the circular flow in motion. Demand and supply must balance, so too assets and liabilities. Inherent in supply is the wherewithal for its consumption. The funds acquired by producers from the banking system to produce goods passes via wages and profits to become the fund that represent the demand for those goods. Another lodestone is Schumpeter. Banks, in his schema, are essential in the creation of new means of payment to finance novel enterprises. The milieu is a capitalist economy founded on private ownership of the means of production. 
Since innovations are carried out by those who do not possess the means of production, banks alter the existing distribution of wealth [6].

Research workers in both camps have been working industriously, but mostly independently. We exploit (what we perceive to be) an identical logic in both strategies to give coherence and closure to two novel institutional devices under active consideration elsewhere. The universal impetus is well known: All countries in the world are in crisis mode, no developing country is decoupled. The credibility and reputation of Central Banks is under strain and, consequently, the device of fiat money is in question. In the present conjuncture, it is worth emphasizing that at the heart of the meltdown is the notion that markets can assess risks based on complex, backward-looking, models. However, the dilemma of development is the introduction of new goods with new technologies and the transfer of resources from traditional occupations to new activities. The insight of the classical two-sector model, echoing Schumpeter, is that investment in new ways, by definition, presented no statistics and appears unduly risky to private investors [7]. The complementary inputs required are unlikely to come about without a massive scale of activity. The current mode of financial regulation, thus, is biased in favor of firms in the formal sector. Still, bank failures have been at the root of contemporary meltdowns and we need to recall that banking, in its familiar form, is defined by an (in)stability condition: the maturity mismatch between both sides of the balance sheets. While, on the one hand, banks might be locked into indivisible arrangements on the assets front, they are obliged to deliver cash (almost) on call as per their liability contracts. Thus, the recommendation of narrow banking is simple: sever the links between the two sides of bank balance sheets. A narrow bank becomes "failure-proof" as its liabilities are backed by cash or near-cash. The lending and investing function can be carried out by a separate division of, say, a holding company. The institutional mechanism has been resurrected as a response to the financial crisis. When the interest bubble burst, for instance, half a trillion dollars of wealth was destroyed. Yet the impact on the economy was slight because little bank lending was involved. Under the scheme, investment banks, hedge funds, and the like can speculate to the extreme with the slightest touch of regulation in place. They would not, however, be permitted to trade or secure credit from banks. Narrow banking was also proposed for a while by Minsky and some limitations of the scheme have recently been reported by Kregel [8]. It turns out that our reformulation along DCI lines and in the context of a self-contained model addresses most of his critique. The macroeconomic theorem that allegedly emerges from the institution of narrow banking is the classical neutrality result. The assets and liabilities of the narrow bank being money or near-monies and being separated from the rest of the economy, it is dichotomized from it. On the other hand, the wage that is the foundation of our framework is not the real but the money wage. Secondly, both Lerner's 'functional finance' as well as Keynes' "socialisation of investment" are natural adjuncts to the case below.

The motive force of our first radical proposal comes from Africa and other poor countries. Since countries in the continent and elsewhere are caught in near-zero levels of economic activity, conditional cash transfer programmes (CCTs) have been worked out and implemented under the aegis of the International Poverty Centre of the UN. Secondly, we examine a bold variant and application of monetary circuit theory to the travails of these economies by Biagio Bossone. The unique feature is the creation of Deposit Creating Institutions (DCIs) that would be independent of the loan disbursement function of non DCIs. The innovation is distinct from narrow banking since the job description of that mechanism is deposit acceptance. Yet, since the purpose of DCIs is to maintain the integrity of the mint and consists of constructing a firewall between the familiar functions of the commercial banks, we claim that the proposal bear a family resemblance to the institution of narrow banking. Our critique of both is, consequently, common. The wage- or consumption- or employment-generating process originates with a gift of cash which wends its way through the economic process. However, closure seems absent in that there is no account of the backup of the giver, of the magnitude and rationale for a particular sum of dollars, or Euros, to start the experiment. The absence of reflux seems particularly surprising in the model of Bossone who is an illustrious exponent of circuit theory. Our contribution lies in proposing a model of fully-backed central bank money. The backing is provided by the fiscal authorities who, in the spirit of narrow banking, are separated from the monetary authorities by a "firewall".

\section{The first moment and the emission of money}

The method of circuit theory is to reason in terms of moments. The first moment consists of money creation in the form of a bank advancing a loan to a businessman for the production of consumer goods. The amount of the loan is the wage bill which, correspondingly, accrues as income to workers. Here, as well, the device has been proposed to ameliorate the crisis. Barnett [9] advises the posting of cash gifts to Americans. At the same time, all projects on the anvil for funding with the Economic Recovery gift cards are posted on the web. For our purposes, the analytical framework is sufficient to appraise the institution of cash disbursements in Africa. Cash transfers have been proposed, as well as disposed of, as an innovation to smooth the consumption of goods and services through the market system [10]. The schemes comprise money disbursements with conditionalities concerning school attendance and so on. Among the issues that have developed is the tension about the time dimension [11, 12, 13]. Funding agencies, often from abroad, impose short-term horizons. Thus, outcomes concerning school attendance and visits to health centres are sought. On 
the other hand, poverty alleviation is a long-term process. CCTs consist of putting cash, not in-kind transfers nor vouchers, in the hands of individuals, not communities or governments. The exchange might be cash for work, but in any case, is independent of interventions like monetization by the state with the provision of microfinance, insurance, and budgetary support. We insist, however, that cash must be given not just for work but meaningful work. The employment hostility of industrial growth has contributed to not just the slackening but the reversal of the Lewis transition [14]. The salient feature of successful growth transitions must be the reduction in absolute employment in agriculture. Advocates claim that the device, while driven by a consumption objective, often has multiplier effects on production through the increased demand for food. Transfers increase the recipient household's demand for goods and services [15]. The next step in the sequence is an increase in demand for labor. For instance, if a programme-ineligible individual is a worker, the increased demand generates employment opportunities. In this connection, mainstream labor market analysis is regarded as unhelpful and has been supplanted by advocates of Integrated Economic Analysis (IEA) [16]. The former is less than useful in poor economies where most of the labor force is self-employed. There is no supply and demand for labor, no employer and employee. The IEA deals with the problem by working out the demand side in the form of creation of jobs and employment. To anticipate our argument we propose to circumvent the shorttermism of external funding by proposing that the cash transfers be promoted under the aegis of the Central Bank. Also, we skirt the charge of paternalism made of the CCTs, that 'means-testing' and 'behavior-testing' move perilously close to social engineering. We regard poverty reduction as coterminous with employment generation. From a public economics perspective, governments may be aware of Pareto-improving outcomes unlike the poor because of informational asymmetry or myopia [17]. The preferences of the poor align with the government here but the former cannot exercise their choices as they lack bargaining power. In a theoretical vein, all this is consistent with Keynes' advocacy of employment generation "on the spot" $[18,19]$. Keynes did not speak of fiscal policy but public works, effective demand is not the same as aggregate demand. The path to full employment is through a universal job guarantee. The government is the employer of last resort at a given base wage. The private sector cannot decide the terms on which to accept government paper. Rather, the Central Bank must institutionalize the issue of its paper to ensure that government spending is not inflationary. A job guarantee scheme will anchor the value of currency by establishing the exchange rate between, say, pesos and an hour of work.

In a similar manner, already referred to, Bossone and Sarr [20] have modified the first step of the monetary circuit. The French-Italian first moment begins with a bank loan to a firm which is received as wages by workers who spend their incomes which return to firms who repay the bank. In their scheme, the first moment begins with a cash transfer to workers. The proposal is to construct a firewall between the lending and the deposit-creating functions of banks. DCIs would collect non-interest-bearing deposits and would distribute money on a non-lending basis, that is with no condition to restitution. Their liabilities would be backed by Central Bank money. Every deposit balance would augmented by a proportion of the depositor's own holdings calculated over a reference period. DCIs would not extend credit but would earn revenue from fees charged for payments services. They would not be permitted to distribute their liquidity to capitalists or non-DCI intermediaries. The latter would fund their assets exclusively with non-debt instruments. The deposits distributed would naturally be the coin of the realm as, in that case, liabilities and assets would be perfectly matched, delivering a risk-free bank. Furthermore, the money would be disbursed to workers. The demand for food, clothing, and housing would rise. Production and production finance for these goods would be stimulated. Higher output would mean greater capital accumulation and so on in second- and higher-order effects. The money distributed to workers would allow firms to capture liquidity as revenues. Capitalists would use non DCIs to purchase inputs and start production. The Central Bank would issue reserves and ensure that the reserves stock is consistent with its projection of the noninflationary production of basics and its objectives with regard to the production of non basics and their prices. Reserve injections and withdrawals would be effected through open market operations with non-DCI intermediaries.

Both the institutional mechanisms under scrutiny have been less than rigorous in working through the role of the government in their taxonomy. We suggest that if history is to be given credence, Central Banks would be integral to the working of both narrow banks as well as DCIs. Furthermore, the government ensures that fiat money is generalised purchasing power by only accepting it in taxes. Therefore, as long as there are taxes, doomsday scenarios about the demise of Central Bank money are premature. Government money, like any other money, must reflux back to the issuer. Still, government money is special because it is redeemable by the mechanism of taxation. Indeed, it is convenient to think of Central Bank money as the pinnacle of a hierarchy of clearing-house measures in society. All payments systems require a clearing house. Thus, tax liabilities are cleared with the Central Bank performing that service for private banks and the treasury. It is imperative to recapture the commercial bank origins of modern Central Banks [21]. Their original mandate was to act as watchdog over the quality of the commercial bills in money markets since these bills would need to be rediscounted in the event of a crisis. The real bills doctrine was founded here. The precept provided both a handle on systemic stability as well as a basis for macroeconomic policy. If the self-liquidating characteristics of commercial bills was above board, being grounded in trade and commerce, whereby the final sales of goods and services was adequate to repay the debt, then both the quality and the volume of such debt was sustainable. Both Keynes and Schumpeter were one in recording both the continuity and change of regime brought about by the 
institution of fiat money [22]. For Keynes, a distinction had to be made between a real exchange economy and a monetary economy with a Central Bank. In the former, money is no more than a device that reduces the costs of exchange. Keynes' typology was matched by Schumpeter's more expansive divide between a pure exchange economy and the capitalist economy. His definition of capitalism included not just the private ownership of the material means of production and the generation of private profits, but also the means of payment by private banks that is sustained by a consensus of all stakeholders in a private enterprise economy. In both cases, it was inadequate to adapt the classical theory founded on a barter economy. At the same time, both acknowledged the essential social nature of the banking system. The essential macroeconomic role of the banking system could be theorised on lines no different from the planning authority in a socialist economy. In other words, the issue of money $M$ is instrumental if it simultaneously is the wage bill of workers $L$ and their wherewithal for consumption $C$ which returns to firms as revenues. The income generated is denoted by $Y^{1}$. The superscript 1 is used to denote the first moment of the circuit. In sum,

$Y^{1}=M=L=C$

The accounting originality of $M$ must be noted. National Income accounts can be looked at as a snapshot, at a point of time. The stock variables give a balance sheet matrix. On the other hand, we can define flow variables during a period of time. What results is a transactions matrix. Money is typically introduced as a stock. It is a legacy of the past. Above it is a flow, an emission that is extinguished as soon as repayments are made. With the introduction of taxes, government expenditure cannot lag behind. The evidence is that the governments were critical in originating virtuous financial-real circuits in the developing world. Even Adam Smith appreciated that the security of property rights alone was insufficient [23]. Instead, governments created large trade monopolies which became the leading joint-stock companies which were responsible for the financial innovations including the emergence of trade in shares. For instance, in Hong Kong with a bank-based system, large banking monopolies modeled on the lines of the Bank of England were created with intimate links with the state. The latter was a banking monopoly for fifty years closely linked to the government. London emerged as a premier financial market due to the monopoly rights granted by the public sector to all leading joint-stock companies. The latter provided long-term loans to the former in exchange for their privileged position. Thus, the emergence of London's stock market went hand in glove with the improvement in public finance. State provisioning of public goods and services includes private consumption goods like education and health that can be provided by the private sector. Let us denote these by $C g$. While they meet the criteria of excludability, positive supply curves, and no external effects, they also possess the trait that benefits can accrue to one citizen at the expense of another [24]. Other arguments sustaining their importance in the macroeconomic fabric include 1. market failure, 2. basic needs considerations, and 3. distributional objectives. In general, neither are benefits nor costs from the delivery of public goods and services equitably distributed. Governments must impose taxes and spend the resulting proceeds to achieve a more equitable distribution of income. The wealthier bear a disproportionately large share of the tax burden, while the poorer bear a proportionately smaller share. It is necessary, then, to examine the claims of advocates of the privatization of public utilities carefully. The experience in Africa has been anything but positive [25]. Despite all the incentives being in place, few private investors have taken any interest in water and electricity and those that have, have done a shoddy job. At the same time, the case for improving performing performance in state-owned firms is overestimated. In the utilities referred to, systematic efforts were made to reduce losses for years before the privatization push. The results were modest. The problem is that publicly-owned and managed enterprises operate at less than cost-recovery tariffs, have provided inadequate and low-quality services, and delivered mainly to the better-off segments of society. Besides, the investment required hugely exceeds any realistic prognosis of internal and external funds. In other words, government expenditure cannot be exempt from the dictates of optimality and efficiency. Distinguishing consumption of private consumption goods by the subscript $p$, we recall the familiar macroeconomic relationships

$Y^{1}=C p+C g+I$ and $I=S$

Now, saving is a proportion $s$ of income and the fiscal authorities tax that income at a rate $t^{1}$. The balanced budget condition, where $T^{1}$ is total tax revenue, is given by

$$
\begin{array}{ll}
C g=T^{1} \\
\therefore \quad Y^{1}-C p-S=t^{1} L \\
\therefore \quad Y^{1}-C p-s Y^{1}=t^{1} Y^{1}
\end{array}
$$

In sum, we have the familiar multiplier relationship

$Y^{1}\left(1-s-t^{1}\right)=C p$

The modern structuralist interpretation is as follows [26]. In a developing economy, the first moment is equivalent to the production of agricultural output and employment. The peasant is back on stage with the World Development Report 2008 stressing that agriculture is the "road to development". The new agrarian question cannot be answered along European lines with the dissolution of the peasantry within industrial societies. Agriculture must be reinvented if the 
Millenium Development Goals are to be met. Peasant societies are not autarkic but subject to internal and external equilibria. These include the labour process, the means of production, and external exchange rates for labor and goods. In that case, assuming a regime of excess capacity, output and wage-goods consumption of workers must be increased. It is safe to assume, of those at a subsistence level, that the propensity to save is arbitrarily low. The efficient and egalitarian recommendation to the fiscal authorities is that taxation of basics should be confined to capitalists in that sector.

\section{The second moment and investment}

Income not consumed is saved and available for investment in capital goods. Here again we distinguish between private $\Delta K p$ and public sector $\Delta K g$ capital accumulation. In other words,

$Y^{1}-(C p+C g)=S=I=\Delta K p+\Delta K g$

Now denote $\Delta K p+\Delta K g$ by $Y^{2}$. The superscript 2 is for the second moment. Suppose, furthermore, that private investment $\Delta K p$ is a proportion $k$ of the level of income in the second moment, $Y^{2}$. In the case of the second moment, the income equals capital expenditure condition of the fisc is given by

$\Delta K g=T^{2}$ and we assume that tax revenue is generated by the taxation of the income of the sector at the rate $t^{2}$. In sum, we have the following identity for the second moment,

$Y^{2}=k Y^{2}+t^{2} Y^{2}$

The solution of the system is

$\left(k+t^{2}\right)=1$

According to the arithmetic, when the propensity to invest of the capital class is low public investment must step in by the appropriately high taxation of the sectoral income. In like manner, if the flow of private investment is robust there is limited cause for public investment. Automatic stabilization is literal here. The arrangement can be regarded as incentive-compatible. Capitalists might be prodded out of pessimistic traps by high tax rates and a high propensity to invest on the part of the capitalist class is encouraged by low tax rates. Note might also be made of the balanced-budget stipulation above. The distinction between deficits in the short run and surpluses in the long run is relevant [27]. As the system approaches full capacity, crowding out will prevail. As long as a government respects an intertemporal budget constraint, increasing public debt is a regressive tax. The propensity to save of capital owners is higher than workers so they own most of the capital. Some of the workers' taxes will be financing net interest payments to capital owners. Since the debt burden reduces the lifetime wealth of workers, a larger public debt entails a smaller share of wealth for their old age. Of interest here is that the two-class model obeys the Cambridge theorem. In the long run, the rate of growth depends only on the saving propensity of capitalists and the rate of profit. It is independent of worker and government savings.

\section{The third moment and closing of accounts}

The money that is created as debt in the first moment is extinguished when debts are repaid. Firms, both private and public sector, for whom banks accounts are created repay their loans when they earn profits generated by workers spending their incomes on basics. The special feature, in our framework, is to introduce the Central Bank as a member of the club of banks. As one organ of the government, it is logically necessary for its fiat money emissions to be backed by the efforts of the other organ of the government, the fiscal authorities. The intention, is must be clarified, is not an endorsement of the Chartalist position; that fiat money is endogenous because it emerges to finance government expenditure [28]. At the same time, we endorse the two-fold distinction in government expenditure: government expenditure on goods and services and the state as employer of last resort when the mint prints and distributes money as wages for the purposes of employment. Elsewhere, Post Keynesians have supported a disaggregation of the familiar macroeconomic aggregates. Thus, in one account, capital budgeting for the public sector [29] is driven by the following identities:

$I=I p+I g, S=S p+S g, C=C p+C g, G=I g+C g$ 
We are now in a position to display our results in the form of pictures. The first is a Godley accounts matrix where $T_{h}$ and $T_{f}$ stand for taxes paid by households and firms respectively. The former would subdivide into taxes paid by capitalists and workers, the latter is sales/indirect taxation.

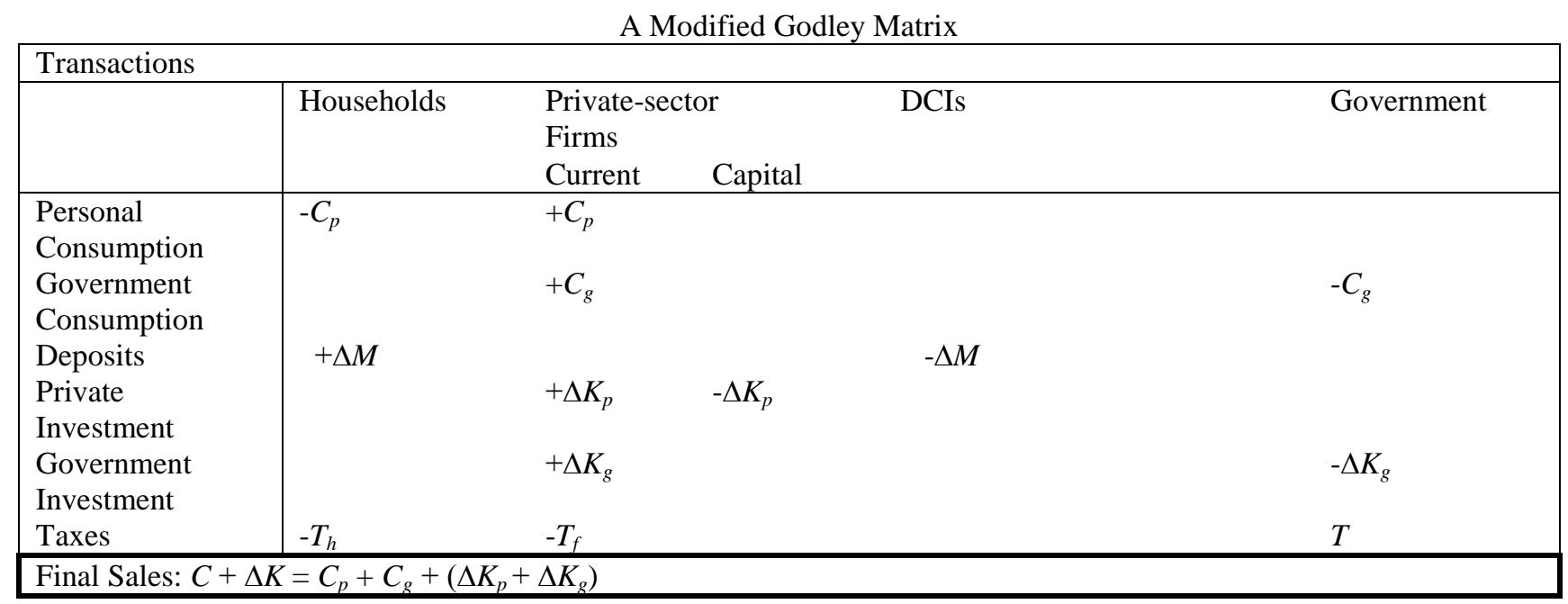

The special features are the replacement of banks by DCIs and, by virtue of the logic of circuit theory, the absence of separate notations for deposits, loans, and cash in balance sheets. A mirror of the balance sheet is a modified monetary circuit.

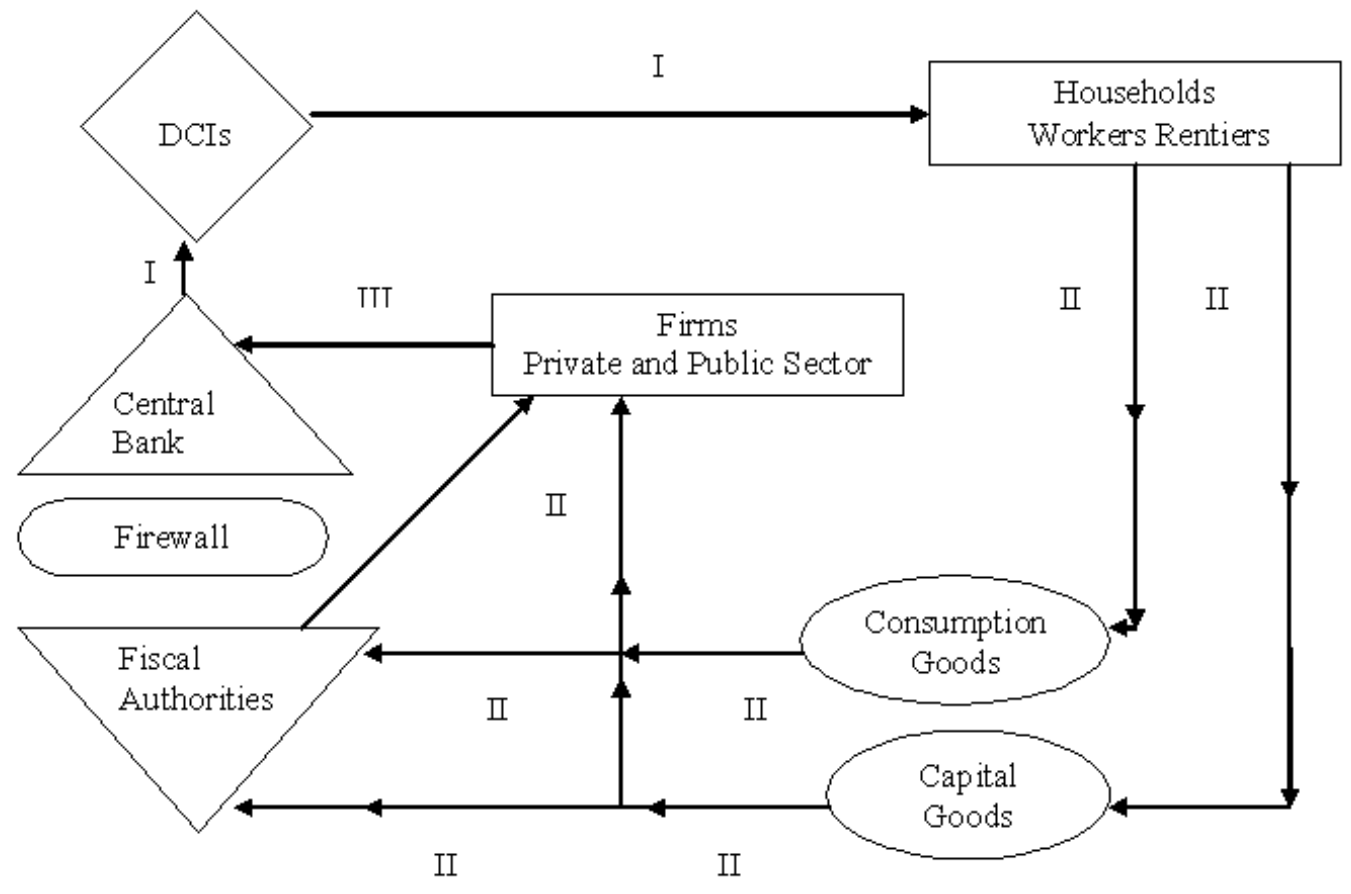

Fig. 1: A modified Bossone Circuit

The three moments are indicated. The Bossone-Sarr diagram (a narrow bank chart) has arrows shooting out of it (piercing it), but none piercing it (shooting out of it). We have filled in this gap with the state. The short message is that the two arms of the government must work in tandem [30, 31]. As Hyman Minsky put it, "big government" and the "big bank" must coordinate for stabilizing an unstable economy. In consultation with each other, they might specify an employment target. Working backwards, and armed with two behavioral coefficients, $k$ and $s$, they can work out the numbers to fill in to accounting frameworks. 


\section{Conclusion}

The mechanisms of deposit creating institutions and conditional cash transfers, independently of each other, have been proposed as devices to ameliorate the problems of disintermediation and impoverishment respectively. The institutions are micro social arrangements and, consequently, have not been subjected to the discipline of aggregate budget constraints. We employ two consistent accounting frameworks, stock-flow- consistent matrices and the monetary circuit to close the loop that originates with a cash transfer. Secondly, we introduce the monetary and fiscal authorities, consistent with competitive principles, to derive the following conclusions: Particularly in poor countries, the monetary authorities must disburse cash through the mediation of banks to employment-generating sectors. The fiscal authorities must act in tandem spending on health and education and the like and in capital accumulation, particularly in situations when private investment is not forthcoming. The means to do this, ensure the stability of the economy, as well as address the problem of gross inequities in income and assets, is steep taxation of non-essentials.

\section{References}

[1] G. Simmel, The Philosophy of Money, Routledge, 1990

[2] C. Gnos, French circuit theory, in: P. Arestis \& M. Sawyer (eds.) A Handbook of Alternative Monetary Economics, Cheltenham, Edward Elgar, 2006.

[3] R. Realfonozo, The Italian circuitist approach, in: P. Arestis \& M. Sawyer (eds) A Handbook of Alternative Monetary Economics, Cheltenham, Edward Elgar. 2006.

[4] H. Matallana, The process of circulation in Quesnay’s Tableau Économique, Universidade de los Andes, Centre de Estudios sobre Désarrollo Económico, Working Paper No. 1, 2008.

[5] D.J,Bezemer, No One Saw This Coming: Understanding Financial Crisis Through Accounting Models, MPRA Paper No. 15767, 2009.

[6] G. Bertocco, Finance and Development: Is Schumpeter's analysis still relevant?, Journal of Banking \& Finance, 32 (2008) $1161-1175$.

[7] D. Rodrik, Industrial Policy: Don't Ask Why, Ask How, Middle East Development Journal, Demo Issue, (2008) 1-29.

[8] J. Kregel, Minsky and the National Banking Proposal: No Solution for Financial Reform, Levy Economics Institute of Bard College Public Policy Brief No.125, 2012.

[9] W.S. Barnett, And a Little Child Shall Lead Them-Economic Recovery in 3 Easy Steps, The Economists' Voice, 6, article 1, (2009).

[10] J. Farrington, R. Slater, Introduction: Cash Transfers: Panacea for Poverty Reduction or Money Down the Drain, in: Theme Issue: Cash Transfers, Development Policy Review, 24 (2006) 499-511.

[11] D. Hailu, F. Soares, Cash Transfers in Africa and Latin America: An Overview, Poverty in Focus No. 15, International Poverty Centre, 2008.

[12] I. Yaschine I., L. Dàvila, Why, When and How Should Beneficiaries leave a CCT Programme?, Poverty in Focus No. 15, International Poverty Centre, 2008.

[13] C. Moore, Funding for CCTs Matter in Honduras and Nicaragua, Poverty in Focus No. 15, International Poverty Centre, 2008.

[14] A. Khan, Employment and Pro-Poor Growth, International Poverty Centre, one pager, 2007.

[15] C. Lehman, Do CCT Programmes Have a Pro-Poor Spillover Effect?, International Poverty Centre, one pager No.98, 2009.

[16] S. Lundström, P. Ronnås, Integrated Economic Analysis for Pro-Poor Growth, International Poverty Centre Conference Paper, 2007.

[17] J. Hoddinott, Is the Conditionality Necessary in Conditional Cash Transfer Programmes? Evidence from Mexico, International Poverty Centre, one-pager, 2008.

[18] P. Tchernova, The Return of Fiscal Policy: Can the New Developments in the New Economic Consensus Be Reconciled with the PostKeynesian View?, Jerome Levy Institute Working Paper No. 539, 2008 A.

[19] P. Tchernova, Keynes' Approach to Full Employment: Aggregate or Targeted Demand?', Jerome Levy Institute Working Paper No. 542, 2008B.

[20] B. Bossone, A. Sarr, Non-Credit Money to Fight Poverty, in: G. Fontana \& R. Realfonzo (eds.) The Monetary Theory of Production, London, Palgrave Macmillan, 2005.

[21] C. Goodhart, D. Tsomocos, Analysis of Financial Stability, Financial Markets Group, London School of Economics, 2007.

[22] G. Bertocco, The characteristics of a monetary economy: a Keynes-Schumpeter approach, Cambridge Journal of Economics, 31 (2007) 101122 .

[23] S. Andrianova, P. Demetriades, C. Xu, Political Economy Origins of Financial Markets in Europe and Asia, Brunel University Centre for Economic Development and Institutions Working Paper No. 08001, 2008.

[24] D. Papadimitriou, Government effects on the Distribution of Income: An Overview, Jerome Levy Institute Working Paper No. $44,2006$.

[25] T. McKinley, Privatising basic utilities in Africa: a rejoinder, International Poverty Centre, 2007A.

[26] E. Vanhaute, The End of Peasantries? Rethinking the Role of Peasantries in a World-Historical View, MPRA Paper No. $1329,2009$.

[27] T. Michl, Rethinking Fiscal Policy, Challenge, 51 (2008) 91-104.

[28] C. Pastoret, Fiscal Policy, Government Intervention and Endogenous Money: Are Chartalist and Circuitist Theories Complementary?, in: C. Gnos \& L-P Rochon (eds.) Post-Keynesian Principles of Economic Policy, Cheltenham, Edward Elgar, 2006.

[29] B. Moore, Shaking the Invisible Hand, Hampshire, Palgrave Macmillan, 2006.

[30] T. McKinley, Why is Africa Constrained from spending ODA?', International Poverty Centre, $2007 \mathrm{~B}$.

[31] G. Epstein, Central Banks as agents of employment creation, DES Working Paper No. 38, 2007. 